\title{
On the first occupational medicine initiatives in Mexico: The Real del Monte miners' hospital
}

\author{
José Luis Gómez ${ }^{1}$ and Carlos Agustín Rodríguez-Paz ${ }^{2}$
}

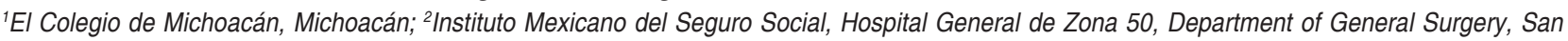
Luis Potosí, Mexico

\begin{abstract}
Despite the legislation of Otto von Bismarck (1815-1898) on social security rights formulated in 1883 in Germany where it is stated that it is the duty of the State to promote the welfare of all members of society, particularly the weakest and most needy, using the means available to them, and the proposals of laws against accidents issued on April 30, 1904 in the State of Mexico in 1904, in the Mexico of the Porfirio Díaz era, providing workers with formal medical care was not contemplated, except in the case of some railway companies, hospitals for the care of patients with occupational diseases were not built. One of these exceptions was the Hospital del Mineral del Real del Monte de Pachuca, founded in the late nineteenth century and after the mining company passed to the Americans in 1906, it was agreed that the company acquired the hospital and equated it with the medical and surgical advances of the time for immediate care of injuries, especially of the orthopedic type, which enabled not only the healing of wounds, but also rehabilitation. This hospital is one of the oldest in Mexico with regard to three disciplines: orthopedics, occupational medicine and rehabilitation. It ceased to operate in 1982, and currently it is a museum with a rich collection of documents and instruments related to the aforementioned disciplines.
\end{abstract}

KEY WORDS: History of medicine. Hospitals. Orthopedics. Rehabilitation. Surgery.

\section{Introduction}

Based on a Bernardino Ramazzini 1700 manuscript (Morbis artificum diatribe or On workers' health), a correlation was established between those diseases that occur as a consequence of working activities and their different divisions (masseurs, miners, chemists, potters, etc.). ${ }^{1}$

Towards the end of the $19^{\text {th }}$ century, the need to provide care to factory and industry workers was identified in the legislation formulated by Bismarck, by means of which social security started. ${ }^{2}$ During World War I, preventing factory workers from ceasing to work was established as a principle, since it was observed to be a decisive factor in victories (production of weapons to finish the enemy). ${ }^{3,4}$ In Latin America, around the decade of 1920, popular movements were initiated, with the purpose for workers' health demands to be addressed.

Mexico's Constitution 27 $7^{\text {th }}$ article was a world icon in terms of legislation on labor safety, by forcing employers to improve workers' health conditions and enable that they were opportunely attended to. ${ }^{5}$ In Mexico, measures were established since the $17^{\text {th }}$ century in the "Laws of the Kingdoms of Indias", 6 by means of which mineds and sugar factory owners had the obligation to maintain a hospital next to their facilities. One decade ago, attorney Felipe Remolina Roqueñi collected information on labor law in our country.

It was in 1948 when a formal medical current emerged, led by Doctor Jorge Fernández Osorio, a pioneer of occupational medicine in Mexico, who was appointed factory-post physician of the Mexican Institute of Social Security. ${ }^{5}$ In 1968, as part of an
Date of reception: 19-02-2016

Date of acceptance: 17-03-2016

DOI://dx.doi.org/10.24875/GMM.M18000138
Gac Med Mex. 2018;154:215-218

Contents available at PubMed www.gacetamedicademexico.com 
agreement between the National Autonomous University of Mexico and the Mexican Institute of Social Security, courses of the Occupational Medicine specialty were initiated. ${ }^{8}$

Before 1948, there are interesting precedents of factories or businesses that promoted measures to prevent their workers from getting sick or cease working due to weather problems or occupational risks inherent to their activities. One example of this was Ferrocarriles de México (Railroads of Mexico), which in 1888 already had a healthcare system for both passengers and workers, characterized by a network where there were first aid posts at long routes' intermediate stations and that later in the 1910-1921 Revolution served to provide care to soldiers in combat. ${ }^{9,10}$

\section{The concept of labor affairs in the Porfiriato}

In the words of Guadalupe Nava Oteo, Mexico emerged as a mining power, especially as a silver producer; when the world became aware of such wealth, the interest of foreign investors was awakened, and their penetration in this activity was intensified during Porfirio Díaz prolonged regimen (a period known as Porfiriato). ${ }^{11,12}$ English and North American companies were the main capital investors in Zacatecas and Guanajuato great mining deposits, ${ }^{13}$ as well as in small mining cities such as Real del Monte in Pachuca, Hidalgo. ${ }^{14}$ With the introduction of foreign capital, deep transformations in the productive processes took place due to the enormous amounts of extracted mineral and the technology employed. However, the arrival of new owners to the mining companies (English and Americans) did not change the working conditions.

Miners had a 12-hour working day, were hired with no perquisites, their salaries were amongst the lowest, were subject to unhealthy working conditions, suffered ill-treatment by foremen and faced discrimination against foreign employees. Workers opposing the progress and peace imposed by General Porfirio Díaz were immediately repressed.

On June 1, 1906, Mexican workers of the Cananea Consolidated Copper Company decided to protest against mistreatment and bad working conditions they were suffering and called all miners of the country to a general strike with the purpose to obtain fairer working days, a more equitable salary to that of their North American or European miner workmates (they asked for a raise from 45 to 50 cents per hour), as well as working conditions modernization and improvement. ${ }^{15}$
They sought to put an end to a problem that occurred in most mines: work accidents that undermined employees' quality of life without them receiving any remuneration whatsoever. It should be noted that, during 1910, 63 accidents occurred at Real del Monte and, three years later, in 1913, there were 98 accidents. ${ }^{16}$ By 1916, which is the year the Social Legislation submitted the Law of Accidents Project to Venustiano Carranza, 104 had occurred..$^{17}$

The Cananea strike was to be followed by the one at Rio Blanco (strike in a textile factory of Río Blanco, Veracruz, on January 7,1907 ) and other rebellions that prepared the way of what later would be the social revolution in Mexico and the creation of constitutional article 123 fraction where a disability insurance was established, funded by the owners of private companies, who would have the responsibility to pay for work-related risks according to estimated figures (1931). ${ }^{17}$

\section{Mining investment in the Porfiriato}

With no doubt, mining has been highly important in Mexico's history. The abundance of minerals in our country has always been one of its greatest riches. Precious metal exploitation has been present in history, from Alexandrians in Egypt and alchemists in the Middle Age to modern states from the $15^{\text {th }}$ century on, which promoted and fostered the search and exploitation of gold and silver mines to fill their vaults. With the finding of a new continent (America), new sources of supply were discovered, which enabled the conquering and colonization of new lands.

Mining constituted, together with agriculture and commerce, the foundation of the colonial economic structure. During $19^{\text {th }}$ century's first 10 years, silver production reached levels that had been never achieved. The years of struggle for independence were to cause a severe mining crisis. ${ }^{18}$

As previously mentioned, mining was favored during the Porfiriato by the arrival of foreign investors, mainly of English and North American origin, who incorporated technological elements that enabled them to obtain larger amounts of silver. An example of this was the acquisition of Sociedad Aviadora de Minas de Real del Monte y Pachuca by the United States Smelting Refining and Mining Company, in an operation that was $\$ 255,400$ pesos worth..$^{19}$ The company lived a great boom under this administration; even when it started operating a few years before the Mexican Revolution (1910), this did not affect it, and by the decade of 1930, the district exploited by the American 
company became the leading silver producer worldwide. By the end of World War II, the drop in the price of silver and taxes applied during President Miguel Alemán Valdés term, caused for North American investors to abandon the mines, which prompted the Mexican government to acquire the shares for 3.5 million dollars in order to prevent the closure of such an important source of employment in the region, turning the Real del Monte company into the first parastatal company.

\section{The Real del Monte de Pachuca hospital}

Modernity promised great earnings, but Porfirio Díaz government monetary policy of implanting the gold standard, silver value low prices and the demand of a strong investment in order to adopt new technology resulted in Sociedad Aviadora de Minas de Real del Monte y Pachuca being acquired in February 12, 1906 by the United States Smelting Refining and Mining Company, which immediately introduced technological advances, such as the use of electricity.

Between September and December 1906, the North American company decided to acquire the Real del Monte miners' hospital and establish a modern and well equipped medical service in order to achieve for patients to be opportunely and carefully attended to. ${ }^{20}$ To afford part of the expenses, the company applied employees and mine workers a 2 to $4 \%$ discount, according to each case, as well as a special fee of 5 cents per individual for building the hospital. ${ }^{21}$ This way, miners and employees of mining companies such as la Blanca, Santa Ana and San Rafael, among others, contributed with a percentage of their salary to the construction of the hospital.

The result was the rehabilitation and re-foundation of Hospital Minero de la Compañía de Real del Monte y Pachuca in 1907, the personnel of which comprised one chief surgeon, two assistant surgeons, one chief nurse, five nurses and one pharmacist. ${ }^{21}$ Located south of the State of Hidalgo, and very differently from Diaz approaches, the company invested on its workers' health and built a medical-surgical unit composed of two large wards, each one equipped with 12 beds, with additional space for other 12 , for a total capacity of 48 beds. ${ }^{21}$ The pharmacy was installed and equipped in November 1907, where the responsible mixed plants with other chemical products to prepare the prescriptions indicated by the doctor. ${ }^{22}$ The radiology equipment was an example of the advanced technology possessed by the hospital: it was provided with wheels, by means of which it could be moved to the hospital wards in order to obtain patients' radiographs without the need to bring them to the X-ray room.

The hospital had a wound-dressing room, where miners who had suffered any accident were received. One area that attracted hospital director attention, doctor A. J. Hoskins, was surgery, which was equipped with a transparent operating table (which enabled obtaining radiographs in the middle of surgery), biopsy clamps, needles and sutures of different calibers, ether and chloroform vials and oxygen tanks, among other surgical implements.

The hospital also had a rehabilitation room, where an early $20^{\text {th }}$ century collection of splints, the only in the country, is currently preserved and where the finger traction devices by means of which fractured fingers and toes were maintained stretched in order for bones to heal, wire rod or stainless steel sieve-like splints that were used to reduce ankle, tibia and fibula injuries, as well as cervical and lumbar spine splints, can be observed, which gives an idea of the main injuries that were cared for.

It draws the attention that the hospital had a shoulder wheel to strengthen shoulder, arm and forearm muscles, staircases with handrails and pulleys to recover the movement of affected parts, which are signs of an incipient rehabilitation medicine in Mexico. It also had orthopedic surgery instruments, with the portable equipment designed by Doctor Alvin Lambotte, Jackson cannulas, endoscopes and cystoscopes standing out, ${ }^{22}$ as well as a wheelchair and a stretcher to move patients to the hospital.

The hospital ceased offering medical services in 1982, when hospital workers were incorporated to Mexican Institute of Social Security health services. It was abandoned until October 2004, when the building was rescued and became the Centro Cultural Nicolás Zavala, with the Occupational Medicine Museum being founded.

\section{Acknowledgements}

For her support, to Belem Oviedo Gámez, director of the Real del Monte Historical Archive heritage, as well as to Aracely Monroy Pérez, Cosmelia Ortiz Velázquez and Héctor Alejandro Ruiz Sánchez.

\section{References}

1. López-Piñero JM. Medicina, historia y sociedad. Antología de clásicos médicos. Tercera edición. España: Ariel; 1973. p. 164-165.

2. Dimitrijevic M, Obradovic G. Funding social insurance. Facta Universitatis (Law and Politics). 2005;3(1):53-61. 
3. Gomero-Cuadra R, Zevallos-Enríquez C, Llapyesan C. Medicina de trabajo, medicina ocupacional y del medio ambiente y salud ocupacional. Rev Med Hered. 2006;17(2):105-108

4. Schott H. Crónica de la medicina. Tercera edición. México: Intersistemas 2003. p. 390.

5. Nava HR. Antecedentes históricos de la salud en el trabajo. En: BarquínCalderón M. Sociomedicina. Cuarta edición. México: Méndez Oteo; 1994: p. 533-536.

6. Título XX, de los mineros y azogueros. En: Recopilación de las Leyes de los Reinos de Indias mandadas a imprimir y publicar por la Majestad Católica del Rey don Carlos II. Madrid: Universidad de Antioquía; 1791

7. Remolina-Roqueñí F. El derecho burocrático en México. México: Secretaría de Gobernación; 2006.

8. Facultad de Medicina. Plan único de especialidades médicas: Medicina del Trabajo. México: Universidad Nacional Autónoma de México; 2003. Disponible en: http://edumed.imss.gob.mx/cst/Acrobat/PUEM\%20MT.pdf.

9. Fajardo-Ortiz G. Los espacios médico-hospitalarios para los ferroviarios (1850-1981). Rev Fac Med UNAM. 2000;43(3):107-109.

10. Rodríguez-Paz CA, Vázquez-Ortega R. Los trenes hospital de la Revolución Mexicana. Cir Gral. 2009;31(1):46-50.

11. Nava-Oteo G. La minería bajo el porfiriato. En: México en el siglo XIX (1821-1910). México: Nueva Imagen; 1980. p. 339-379.

12. von Mentz B. Trabajo minero y control social durante el porfiriato. Las operaciones de dos poblaciones contrastantes. Historia Mexicana. 2001;50(3):555-607

13. Meyer-Cosío FJ. La minería en Guanajuato. México: El Colegio de Michoacán/Universidad de Guanajuato; 1998. p. 65-98.
14. Flores-Clair E. Minería y población, Real del Monte 1791-1865. Dimensión Antropológica. 1997;11:7-35. Disponible en: http://www.dimensionantropologica.inah.gob. $\mathrm{mx} / \mathrm{p}=1388$.

15. Cárdenas-García N. La huelga de Cananea en 1906. Una interpretación. Estudios Sociológicos. 1998;16(46):117-146.

16. Licona-Duarte VM. Los mineros "cornish" en el distrito minero de Pachuca y Real del Monte: una minería étnica en México (1849-1906). México: Universidad Nacional Autónoma de México; 1998. p. 5.

17. Benejam MA, Brown-Villalba C, Celis L, Flores-Hernández B, et al. Historia del Instituto Mexicano del Seguro Social. Los primeros años 1943-1944. México: Instituto Mexicano del Seguro Social; 1980, p. 19

18. Urrutia M, Nava-Oteo G. La minería (1821-1880). En: Cardoso C. México en el siglo XIX (1821-1910). México: Nueva Imagen; 1992. p. 119.

19. Ortega-Morel J. Tecnología y minería: la empresa norteamericana de Real del Monte y Pachuca. Tesis, Universidad Autónoma de Hidalgo, Hidalgo, México, p. 42

20. Hemerobiblioteca del Mineral del Real del Monte. Fondo Norteamericano. Sección Serie Archivo Especial de la Dirección General, Subserie General, expediente 37. vol. 48.

21. González F, Grothe A, Salazar L. La industria minera de México. Volumen I. México: Imprenta y Fototipia de la Secretaría de Fomento; 1911. p. $112-115$.

22. Oviedo-Gámez B. Centro Cultural Nicolás Zavala, Museo de Medicina Laboral [Catálogo]. México: Archivo Histórico y Museo de Minería; 2005. p. 12. 